\title{
Novel oxadiazole- and triazole-based calixarene derivatives: synthesis and extraction properties
}

\author{
Ali Osman KARATAVUK ${ }^{1, *}$ \\ ${ }^{1}$ Trakya University, Faculty of Science, Department of Chemistry, \\ Edirne, 22030, TURKEY \\ Geliş Tarihi (Received Date): 16.03.2021 \\ Kabul Tarihi (Accepted Date): 04.10.2021
}

\begin{abstract}
Two new calixarene derivative compounds bearing oxadiazole and triazole groups were synthesized. The final products were illuminated by using ${ }^{1} \mathrm{H}-\mathrm{NMR},{ }^{13} \mathrm{C}-\mathrm{NMR}, \mathrm{FT}-\mathrm{IR}$ and HR-MS. The extraction efficiency of these compounds was investigated in the removal of methyl orange. In addition, the effect of $\mathrm{H}^{+}$ion concentration in extraction studies conducted in different $\mathrm{pH}$ ranges and the effect of $\mathrm{NaCl}$ concentration on the percentage of extraction was examined. The results obtained showed that the percentage of extraction was highly dependent on the $H^{+}$ion concentration. It was found that the percentage of methyl orange removal was $53.3 \%$ for triazole derivatives 5 .
\end{abstract}

Keywords: Calixarene, oxadiazole, triazole, extraction.

\section{Yeni okzadiazol ve triazol bazlı kaliksaren türevlerinin sentezi ve ekstraksiyon özellikleri}

Öz

Bu çalışmada, okzadiazol ve triazol türevi taşıyan iki yeni kaliksaren türevi bileşik sentezlendi. Elde edilen nihai ürünlerin yapılarl ${ }^{1} \mathrm{H}-\mathrm{NMR},{ }^{13} \mathrm{C}-\mathrm{NMR}$, FT-IR ve HR-MS analizleri ile aydınlatıldı. Bu bileşikler ile sıvı-sıvı ekstraksiyonu yapılarak sulu çözeltideki metil oranjın uzaklaştırılmasında etkinlikleri değerlendirildi. Ayrıca ekstraksiyon yüzdesi üzerine $\mathrm{H}^{+}$iyonu konsantrasyonu ve $\mathrm{NaCl}$ konsantrasyonunun etkisi incelendi. Elde edilen sonuçlar ekstraksiyon yüzdesinin $H^{+}$iуonu

\footnotetext{
*Ali Osman KARATAVUK, aosmankaratavuk@trakya.edu.tr, http://orcid.org/0000-0001-6616-4065
} 
konsantrasyonuna bağlı olduğunu gösterdi. Triazol türevi 5 için sulu ortamdan metil oranjın uzaklaştırılma yüzdesi \% 53.3 olarak bulundu.

Anahtar kelimeler: Kaliksaren, okzadiazol, triazol, ekstraksiyon.

\section{Introduction}

The phenolic hydroxyl groups and the para positions of calixarenes can easily be functionalized to obtain molecules with desired sizes [1-5]. In addition, the meta positions and the methylene bridges can also be functionalized [6-9]. Obtaining different conformations by using different reagents is another aspect that makes this study an attractive one [10-12]. Since calixarene skeleton is very versatile and can be converted to many compounds, it has an important role in host-guest chemistry [13-15]. For this reason, many extraction and fluorescence studies have been performed with these compounds [16-20]. Especially, in extraction studies, calixarene derivatives seem to be particularly effective in removing carcinogenic azo dyes [21-23]. Since the derivatives of these compounds and their polymeric structures show good results in the removal of azo dyes, this makes the synthesis of calixarene derivatives important in such studies [24-27].

1,3,4-oxadiazole and 1,2,4-triazole derivatives are known to exhibit biological activities such as anticancer, antimicrobial, antifungal and antiviral [28-32]. In addition to biological properties, 1,3,4-oxadiazole has a great advantage in material science due to its various electronic properties [33-35]. These two structures can act as ligands and easily interact with some metal ions because of their heteroatoms [36, 37]. In the literature, calixarene derivatives with heterocyclic structure show very effective results in removing azo dyes [21-23,24]. Although different methods and structures are used, the calixarene molecule appears to be a good host for azo dyes.

Since azo dyes are not biodegradable, they emerge as an important environmental problem in waste water [38]. In addition to environmental problems, azo dyes show various toxic properties in the human body such as cancer $[39,40]$. One of the anionic dyes used academically and industrially among azo dyes is methyl orange [39, 41]. Therefore, studies on removing azo dyes such as methyl orange from wastewater have increased considerably. The structure of methyl orange is shown in figure 1 .

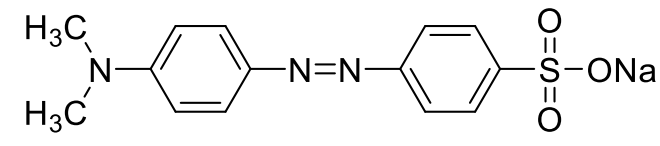

Figure 1. Structure of methyl orange

In our study, we present two novel calixarene derivatives containing 1,2,4-triazole and 1,3,4-oxadiazole. The extraction efficiency of these two compounds were investigated in the removal of methyl orange. In addition, the effect of $\mathrm{H}^{+}$ion concentration in extraction studies conducted in different $\mathrm{pH}$ ranges and the effect of $\mathrm{NaCl}$ concentration on the percentage of extraction was examined. 


\section{Material and method}

\subsection{General}

All chemical reagents and solvents were purchased from Merck, Acros and SigmaAldrich and used without any purification. Solvents were dried with $3 \AA$ molecular sieve activated and used analytical grade. Varian Mercury Plus $300 \mathrm{MHz}$ was used for ${ }^{1} \mathrm{H}$ and ${ }^{13} \mathrm{C}$ NMR analysis. Fourier Transform Infrared analyses were performed on the PerkinElmer Frontier FT-IR Spectroscopy. Waters SYNAPT G1 MS was used for HRMS results. Shimadzu model UV-1700 spectrophotometer was used for UV-Vis. measurements. Thin Layer chromatography (TLC) purchased from Merck was used to monitorize all reactions. Silica gel 60 purchased from Merck was used for column chromatography.

\subsection{Synthesis of 25,27-Bis(4-bromobutoxy)-26,28-dihydroxy-5,11,17,23-tetra(tert- butyl)calix[4]arene}

Compound 2 ( $1 \mathrm{~g}, 1.54 \mathrm{mmol})$, 1,4-Dibromobutane $(3.33 \mathrm{~g}, 15.4 \mathrm{mmol})$ and potassium carbonate $\left(223.6 \mathrm{mg}, 1,62 \mathrm{mmol}\right.$ ) were taken in a flask and added $80 \mathrm{ml} \mathrm{CH}_{3} \mathrm{CN}$. The mixture was refluxed for $24 \mathrm{~h}$. Organic solvent was evaporated under vacuum. The

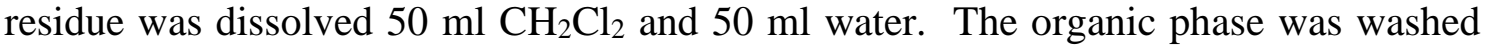
twice more with water. The organic phase was dried over $\mathrm{MgSO}_{4}$. The solvent was evaporated under vacuum. The residue was purified by using column chromatography on silica gel with $\mathrm{CH}_{2} \mathrm{Cl}_{2}: \mathrm{n}-\mathrm{Hexane}(2: 3)$. Yield: $66.7 \%$

2.3. Synthesis of 25,27-Bis[4-(5-(pyridin-3-yl)-1,3,4-oxadiazol-2-ylthio)butoxy]-26,28dihydroxy-5,11,17,23-tetra(tert-butyl)calix[4]arene

5-(3-Pyridyl)-1,3,4-oxadiazole-2-thiol $(42.2 \mathrm{mg}, 0.24 \mathrm{mmol})$ and potassium carbonate (31.5 mg, $0.23 \mathrm{mmol}$ ) were taken in a flask and added $30 \mathrm{~mL} \mathrm{CH}_{3} \mathrm{CN}$. The mixture was refluxed for 30 minutes. Compound $3(0.1 \mathrm{~g}, 0.11 \mathrm{mmol})$ in $20 \mathrm{~mL} \mathrm{CH}_{3} \mathrm{CN}$ was added to the mixture drop by drop. The reaction mixture was refluxed for an additional $24 \mathrm{~h}$. Organic solvent was evaporated under vacuum. The residue was dissolved $50 \mathrm{~mL}$ $\mathrm{CH}_{2} \mathrm{Cl}_{2}$ and $50 \mathrm{~mL}$ water. The organic phase was washed twice more with water. The organic phase was dried over $\mathrm{Na}_{2} \mathrm{SO}_{4}$. The solvent was evaporated under vacuum. The residue was purified by using column chromatography on silica gel with $\mathrm{CH}_{2} \mathrm{Cl}_{2}: \mathrm{CH}_{3} \mathrm{OH}$ (40:1). Yield: $63.5 \%$

${ }^{1} \mathrm{H}$ NMR (CHLOROFORM-d, 300MHz): $\delta$ (ppm) 9.21 (br. s, 2H), 8.74 (br. s, 2H), 8.24 $(\mathrm{d}, J=7.9 \mathrm{~Hz}, 2 \mathrm{H}), 7.41(\mathrm{~s}, 4 \mathrm{H}), 7.04(\mathrm{~s}, 4 \mathrm{H}), 6.80(\mathrm{~s}, 4 \mathrm{H}), 4.24(\mathrm{~d}, J=12.9 \mathrm{~Hz}, 4 \mathrm{H}), 4.06$ (t, $J=5.9 \mathrm{~Hz}, 4 \mathrm{H}), 3.60(\mathrm{t}, J=7.0 \mathrm{~Hz}, 4 \mathrm{H}), 3.31(\mathrm{~d}, J=13.2 \mathrm{~Hz}, 4 \mathrm{H}), 2.29-2.42(\mathrm{~m}, 4 \mathrm{H})$, 2.17 - $2.29(\mathrm{~m}, 4 \mathrm{H}), 1.29(\mathrm{~s}, 18 \mathrm{H}), 0.96(\mathrm{~s}, 18 \mathrm{H}) ;{ }^{13} \mathrm{C}$ NMR (CHLOROFORM-d, $75 \mathrm{MHz}): \delta(\mathrm{ppm}) 165.5,163.8,152.4,150.8,149.9,147.8,147.2,141.8,134.0,132.7$, 127.9, 125.8, 125.3, 123.9, 120.4, 76.0, 34.2, 34.0, 32.9, 31.9, 31.2, 29.2, 26.5; FTIR $\left(\mathrm{cm}^{-1}\right): 3394.9,1602.9$; HRMS (ESI-MS) $\mathrm{m} / \mathrm{z}$ : $[\mathrm{M}+\mathrm{H}]^{+}$Calcd for $\mathrm{C}_{66} \mathrm{H}_{79} \mathrm{~N}_{6} \mathrm{O}_{6} \mathrm{~S}_{2}$ 1115.5503; found 1115.5466 .

\subsection{Synthesis of 25,27-Bis[4-(5-(pyridin-3-yl)-4H-1,2,4-triazol-3-ylthio)butoxy]-} 26,28-dihydroxy-5,11,17,23-tetra(tert-butyl)calix[4]arene

5-(3-pyridyl)-4H-1,2,4-triazole-3-thiol $(0.21 \mathrm{~g}, 1.2 \mathrm{mmol})$ and potassium carbonate (165 $\mathrm{mg}, 1.2 \mathrm{mmol})$ were taken in a flask and added $60 \mathrm{~mL}$ THF. The mixture was stirred for 2 hours at room temperature. Compound $3(0.5 \mathrm{~g}, 0.54 \mathrm{mmol})$ was added to the mixture. The reaction mixture was stirred for an additional $24 \mathrm{~h}$. The temperature was adjusted to $50{ }^{\circ} \mathrm{C}$ and stirred for 2 days. Organic solvent was evaporated under vacuum. 
The residue was dissolved $70 \mathrm{~mL} \mathrm{CH}_{2} \mathrm{Cl}_{2}$ and $70 \mathrm{~mL}$ water. The organic phase was washed twice more with water. The organic phase was dried over $\mathrm{Na}_{2} \mathrm{SO}_{4}$. The solvent was evaporated under vacuum. The residue was purified by using column chromatography on silica gel with $\mathrm{CH}_{2} \mathrm{Cl}_{2}: \mathrm{CH}_{3} \mathrm{OH}$ (40:1 to 20:1). Yield: $71.5 \%$

${ }^{1} \mathrm{H}$ NMR (CHLOROFORM-d, 300MHz): $\delta$ (ppm) 9.35 (br. s., 2H), 8.64 (d, J=4.7 Hz, 2H), 8.35 (d, J=6.4 Hz, 2H), 7.49 (br. s., 2H), 7.32 - 7.42 (m, 2H), 7.06 (s, 4H), 6.80 (s, 4H), 4.28 (d, J=12.9 Hz, 4H), 4.01 (br. s., 4H), 3.41 (br. s., 4H), 3.33 (d, J=12.9 Hz, 4H), 2.14 (br. s., 8H), 1.29 (s, 18H), 0.97 (s, 18H); ${ }^{13} \mathrm{C}$ NMR (CHLOROFORM-d, $75 \mathrm{MHz}): \delta(\mathrm{ppm}) 159.0,155.6,150.6,150.0,149.9,147.5,147.3,142.1,134.5,132.8$, 128.1, 126.7, 125.8, 125.4, 124.1, 76.2, 34.2, 34.1, 33.5, 32.0, 31.3, 29.3, 26.9. FTIR $\left(\mathrm{cm}^{-1}\right)$ : 3362.7, 1604.8; HRMS (ESI-MS) $\mathrm{m} / \mathrm{z}$ : $[\mathrm{M}+\mathrm{H}]^{+}$Calcd for $\mathrm{C}_{66} \mathrm{H}_{81} \mathrm{~N}_{8} \mathrm{O}_{4} \mathrm{~S}_{2}$ 1113.5822; found 1113.5769 .

\subsection{Extraction studies}

Extractions were performed following similar methods in the literature [21-23]. Firstly, $1 \times 10^{-5} \mathrm{M}$ solutions of methyl orange containing $0.2 \mathrm{~mol} / \mathrm{L} \mathrm{NaCl}$ at $\mathrm{pH}=3,5,7$ and 9 and $1 \times 10^{-3} \mathrm{M}$ solutions of compounds 4 and 5 in dichloromethane were prepared. 10 $\mathrm{mL}$ of dye solution and $10 \mathrm{~mL}$ of calixarene solution were mixed at $25^{\circ} \mathrm{C}$ and $150 \mathrm{rpm}$ for 1 hour. The phases were allowed to separate for 30 minutes. The water phase was taken and its absorbance was measured in UV-Vis spectrophotometry at $463 \mathrm{~nm}$. The percentage of extraction was calculated using the equation below [21-23].

$$
\% \text { Extraction }=\frac{C_{1}-C_{2}}{C_{1}} \times 100
$$

The methyl orange concentration in the initial solution is $\mathrm{C}_{1}$. The methyl orange concentration in the final solution is $\mathrm{C}_{2}$.

\section{Result and discussion}

In order to obtain these structures, first, p-tert-butylcalix[4]arene was synthesized by using the procedure from Gutsche [42]. In the next step, two equivalent 1,4dibromobutane was attached to the two phenolic hydroxyl groups [43]. Finally, dibromo calixarene derivative was treated with 5-(3-pyridyl)-4H-1,2,4-triazole-3-thiol and 5-(3-pyridyl)-1,3,4-oxadiazole-2-thiol in $\mathrm{K}_{2} \mathrm{CO}_{3} / \mathrm{CH}_{3} \mathrm{CN}$ system. The synthetic steps are shown in scheme 1 below. The final products were characterized by using ${ }^{1} \mathrm{H}$ NMR, ${ }^{13} \mathrm{C}$ NMR, FT-IR and HRMS. The compounds 4 and 5 which produced in three steps were afforded in $63.5 \%$ and $33 \%$ yield, respectively. The ${ }^{1} \mathrm{H}$ NMR spectral data of Compound 4 showed that the methylene protons attached to the bromide atom shifted from $3.65 \mathrm{ppm}$ to $3.60 \mathrm{ppm}$. The presence of pyridine protons at 8.24, 8.74 and 9.21 ppm in the aromatic region as well as phenol protons support the structure. For the compound 4 , the presence of fifteen carbons of the oxadiazole, pyridine and calixarene were confirmed by ${ }^{13} \mathrm{C}$ NMR. In addition, the methylene carbon attached to sulfur atom were found under $\mathrm{CDCl}_{3}$ peaks around $77 \mathrm{ppm}$ in ${ }^{13} \mathrm{C}$ NMR spectra. HRMS spectrometry gave $1115.5466[\mathrm{M}+\mathrm{H}]^{+}$which supports the accuracy of the structure. In compound 5, the methylene protons attached to sulphur atom shifted from $3.65 \mathrm{ppm}$ to $3.41 \mathrm{ppm}$. In addition, the ${ }^{1} \mathrm{H}-\mathrm{NMR}$ spectra of the two products obtained showed that the presence of two doublet peaks of methylene protons around 3.32 and $4.26 \mathrm{ppm}$ with characteristic geminal coupling constants confirms that cone conformation is preserved. 
In the aromatic region, three peaks indicating the presence of the pyridine were observed at $8.35,8.64$ and $9.35 \mathrm{ppm}$. 15 peaks due to calixarene, triazole and pyridine were observed in aromatic region in ${ }^{13} \mathrm{C} \mathrm{NMR}$. The methylene carbons attached to sulphur atom were seen under the $\mathrm{CDCl}_{3}$ peaks around 77. Mass spectrometry gave $1113.5769[\mathrm{M}+\mathrm{H}]^{+}$which confirms the formation of the structure.

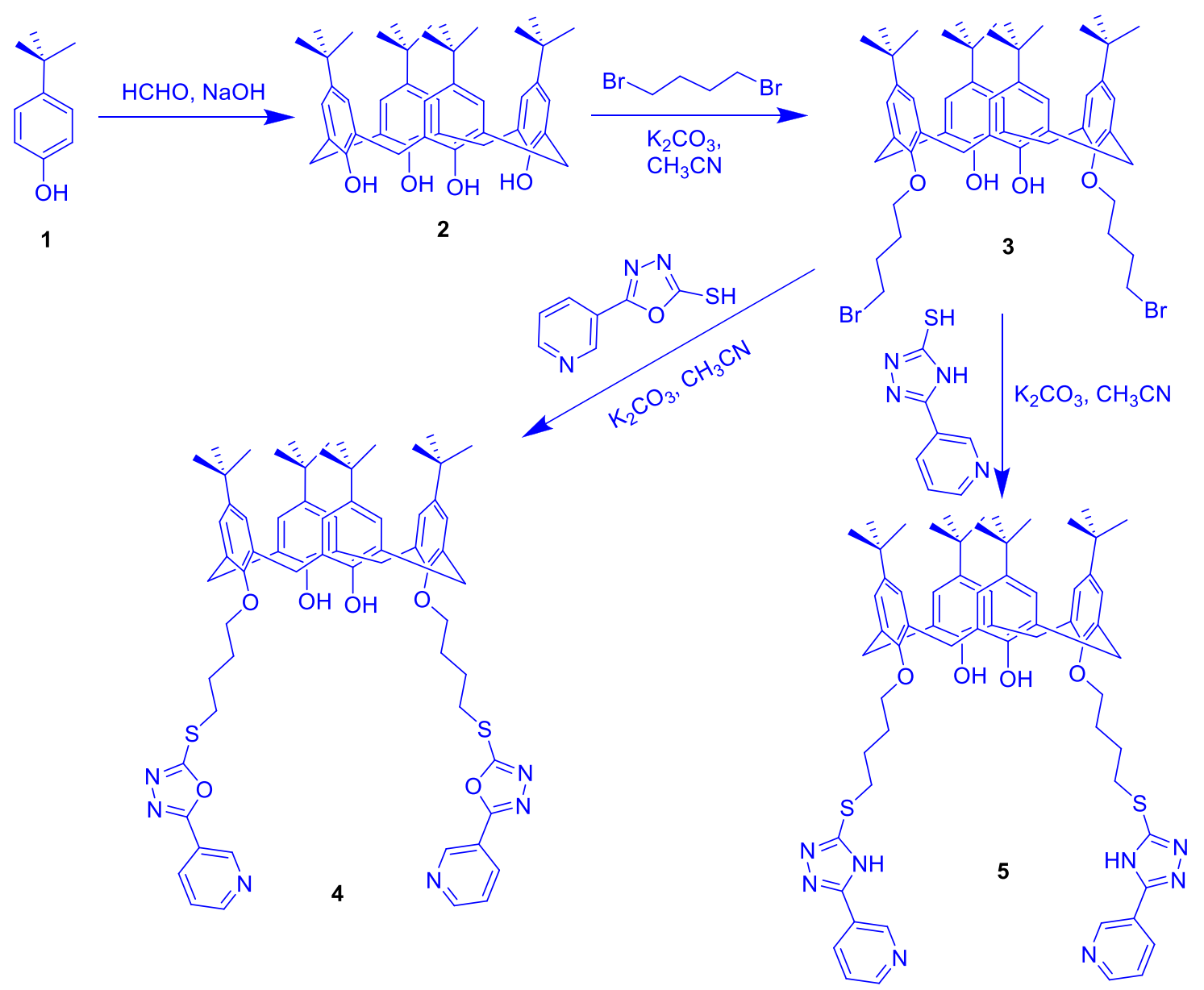

Scheme 1 . The synthetic route to the compounds 4 and 5

After the synthesis of the desired molecules, extraction studies were performed. In previous studies, it is seen that $\mathrm{NaCl}$ contributes significantly to the extraction efficiency [39]. Therefore, the initial dye solutions containing $0.2 \mathrm{~mol} / \mathrm{L} \mathrm{NaCl}$ were prepared at different $\mathrm{pH}$ ranges. $\mathrm{pH}$ ranges of 3,5, 7 and 9 were selected in the study. Due to phenolic protons on calixarene, $\mathrm{pH}=11$ was not studied. In the extraction with compound 4 , a very small amount of methyl orange was found to be extracted at $\mathrm{pH}=3$ and $\mathrm{pH}=9$. While the extraction efficiency was $14.1 \%$ at $\mathrm{pH}=3$, it was $14.7 \%$ at $\mathrm{pH}=$ 9. At the other two $\mathrm{pH}$ levels, it was observed that methyl orange could not be removed at all. In the extraction with compound 5, it was determined that the extraction increased significantly at $\mathrm{pH}=3$ and was found to be $53.3 \%$. At $\mathrm{pH}=5,7$ and 9 , it was measured as $4.2 \%, 0 \%$ and $18.6 \%$, respectively. The extraction percentages for compound 4 and compound 5 are shown in figure 2 . Since the pyridine groups on these two compounds could not show their basic character at $\mathrm{pH}=7$, the extraction percentages were found to be zero for both compounds. At $\mathrm{pH}=5$, however, the fact that compound 5 has a slight difference on the extraction percentage is due to the weak basic character of the triazole group on the structure. These data support that the basic 
groups are protonated in the acidic solution and methyl orange is transported by hydrogen bonding.

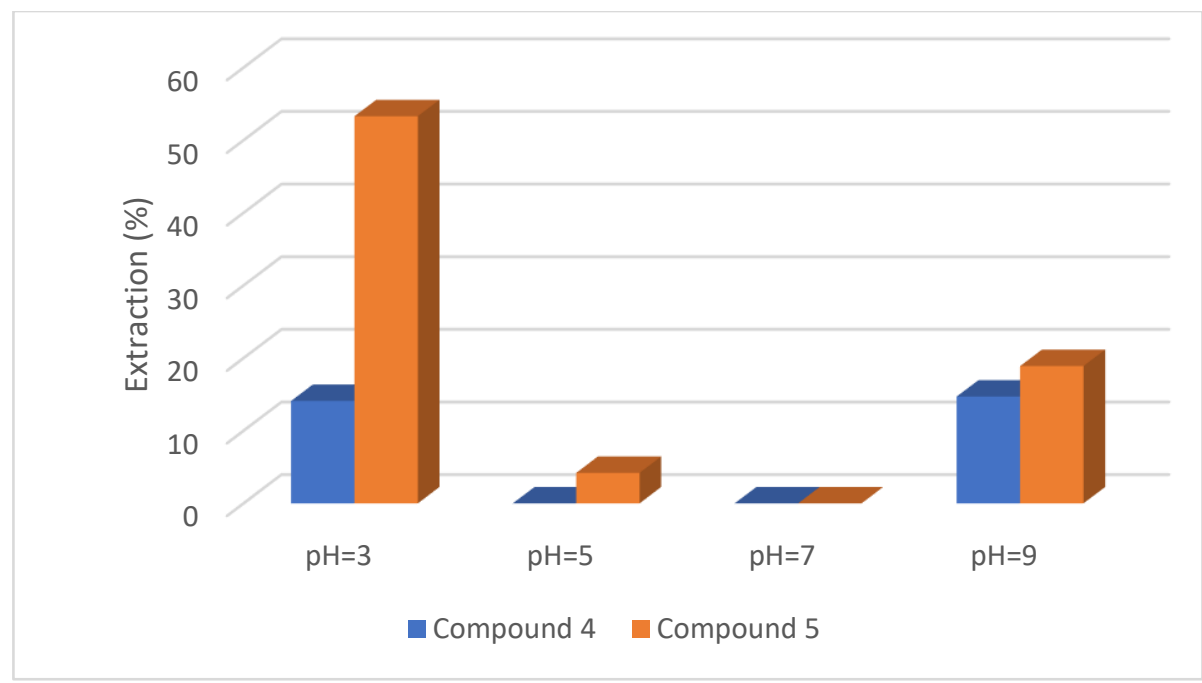

Figure 2. Percentage extraction values at different $\mathrm{pH}$ for compound 4 and compound 5

Sodium chloride has a significant effect in the removal of these structures because it provides ionic balance and significantly reduces the solubility of azo dyes [22, 23]. Therefore, methyl orange solutions containing different concentrations of $\mathrm{NaCl}$ were prepared to examine the effect on extraction efficiency. This study was conducted at the $\mathrm{pH}$ at which both molecules are most effective. $\mathrm{pH}=9$ was selected for compound 4 , while $\mathrm{pH}=3$ was selected for compound 5. As expected for compound 4 , the increase in $\mathrm{NaCl}$ concentration slightly increased the extraction percentage, while for compound 5 it was observed to decrease. The effect of $\mathrm{NaCl}$ concentration on the extraction percentage is shown in figure 3. For compound 4, the solubility of methyl orange decreased with the common ion effect, while for compound 5, a decrease in the extraction percentage was observed due to the commutative ion interferences [22, 23].

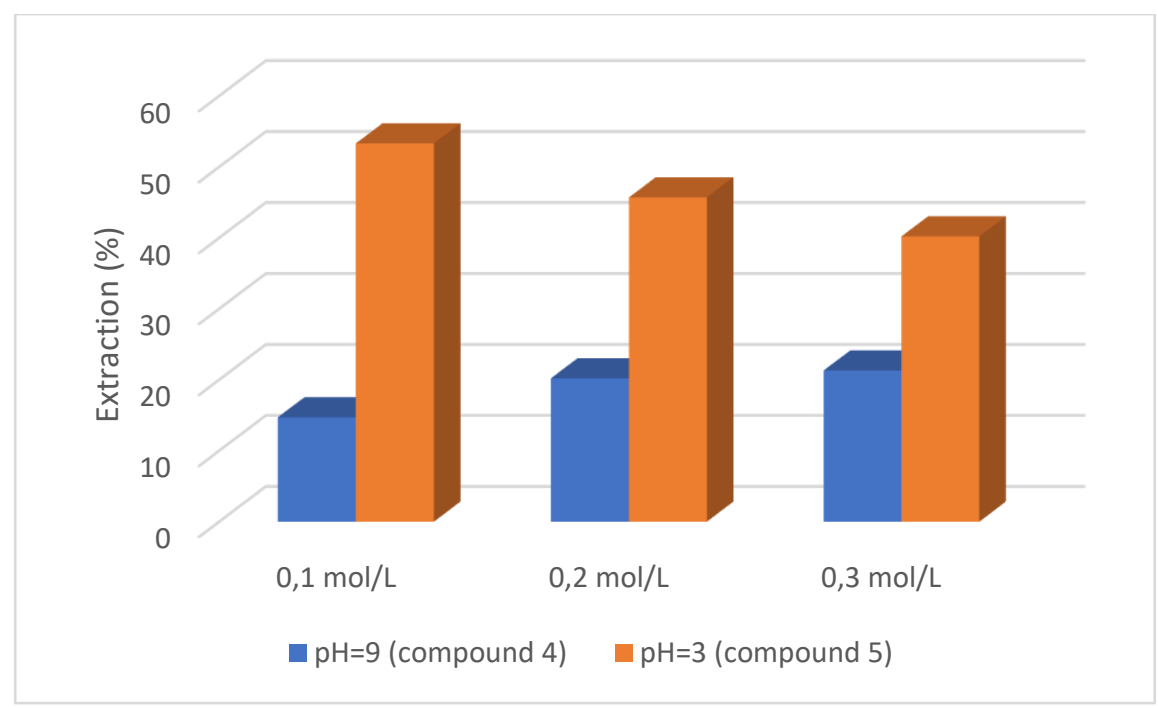

Figure 3. Effect of $\mathrm{NaCl}$ on percentage of extraction at $\mathrm{pH}=9$ for compound 4 and at $\mathrm{pH}=3$ for compound 5 
Although there is only one different atom between compound 4 and compound 5, this difference in extraction percentage can be explained by the weak basic character of triazole. It is thought that the triazole ring is protonated under acidic conditions and as a result, it is transported by hydrogen bonding with the sulfonate oxygen on methyl orange. The proposed structure for the transport of methyl orange is shown in figure 4.

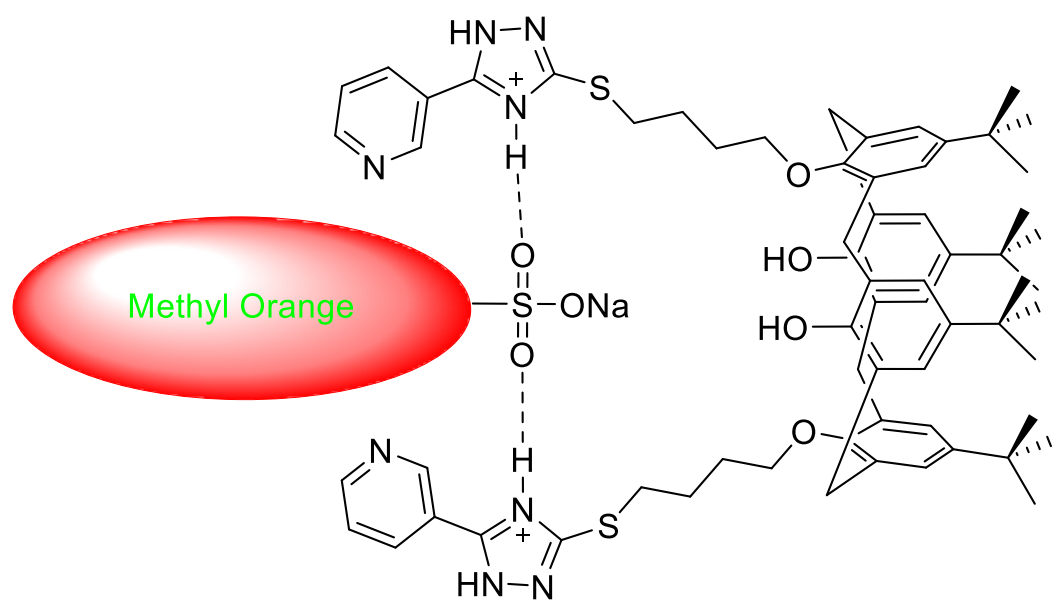

Figure 4. The proposed structure for the transport of methyl orange at $\mathrm{pH}=3$

\section{Conclusion}

In this study, two novel calixarene derivatives containing oxadiazole and triazole groups were described. The structures of these compounds were characterized by spectroscopic techniques such as ${ }^{1} \mathrm{H}-\mathrm{NMR},{ }^{13} \mathrm{C}-\mathrm{NMR}$, FT-IR and HR-MS. Liquid-liquid extraction of methyl orange, known as azo dye, was carried out at different $\mathrm{pH}$ values. The results showed that the highest percentage of extraction was $53.3 \%$ with compound 5 at $\mathrm{pH}=3$. In addition, the extraction efficiency was found to be based on ionic strength and $\mathrm{pH}$.

\section{References}

[1] Molad, A., Goldberg, I. and Vigalok, A., Tubular Conjugated Polymer for Chemosensory Applications, Journal of American Chemical Society, 134, 17, 7290-7292, (2012).

[2] Troisi, F., Pierro, T., Gaeta, C. and Neri, P., The p-Bromodienone Route to Nucleophilic Functionalization of Calixarene Exo Rim, Organic Letters, 11, 3, 697-700 (2009).

[3] Cao, X., Luo, L., Zhang, F., Miao, F., Tian, D. and Li, H., Synthesis of a deep cavity calix[4]arene by fourfold Sonogashira cross-coupling reaction and selective fluorescent recognition toward p-nitrophenol, Tetrahedron Letters, 55, 12, 2029-2032, (2014).

[4] Xu, Z., Lü, Z.S. and Chen, L., Enhanced etherification of calix[4]arenes by microwave irradiation, Journal of Inclusion Phenomena and Macrocyclic Chemistry, 88, 1-2, 77-83, (2017).

[5] Drigo, N.A., Gorbunov, A.N., Gorbunov, D.N., Talanova, M.Y., Kardasheva, Y.S., Kovalev, V.V., Maximov, A.L. and Vatsouro, I.M., Synthesis of polyfunctional phosphorus-containing calixarenes in cycloaddition reactions of 
azides to alkynes, Chemistry of Heterocyclic Compounds, 52, 12, 1042-1053, (2016).

[6] Shalev, O. and Biali, S.E., C-Me Bond Formation at All Methylene Bridges of the Calix[4]arene Scaffold, Organic Letters, 20, 11, 3390-3393, (2018).

[7] Poms, D., Itzhak, N., Kuno, L. and Biali, S.E. Calixradialenes: Calixarene Derivatives with Exocyclic Double Bonds, Journal of Organic Chemistry. 79, 2, 538-545, (2014).

[8] Tlustý, M., Slavík, P., Dvořáková, H., Eigner, V. and Lhoták, P., Synthesis and study of calix[4]arenes bearing azo moieties at the meta position, Tetrahedron, 73, 9, 1230-1237, (2017).

[9] Stejskal, F., Eigner, V., Dvořáková, H., Cuřínová, P. and Lhoták, P., Direct C-H azidation of calix[4]arene as a novel method to access meta substituted derivatives, Tetrahedron Letters, 56, 39, 5357-5361, (2015).

[10] Toma, L., Legnani, L., Compostella, F., Giuliani, M., Faroldi, F., Casnati, A. and Sansone, F., Molecular Architecture and Symmetry Properties of 1,3-Alternate Calix[4]arenes with Orientable Groups at the Para Position of the Phenolic Rings, Journal of Organic Chemistry. 81, 20, 9718-9727, (2016).

[11] Slavík, P., Eigner, V. and Lhoták, P., A general method for obtaining calix[4]arene derivatives in the 1,2-alternate conformation, Tetrahedron, 72, 41, 6348-6355, (2016).

[12] Yang, Y., Cao, X., Purkiss, D.W., Cannon, J.F. and Bartsch, R.A., Di-ionizable calix[4]arene-1,3-crown-4 ligands in 1,3-alternate, cone, and partial-cone conformations: synthesis and metal ion extractions, Tetrahedron, 68, 10, 22332244, (2012).

[13] Augusto, A.S., Miranda, A.S., Ascenso, J.R., Miranda, M.Q., Félix, V., Brancatelli, G., Hickey, N., Geremia, S. and Marcos, P.M., Anion Recognition by Partial Cone Dihomooxacalix[4]arene-Based Receptors Bearing Urea Groups: Remarkable Affinity for Benzoate Ion, European Journal of Organic Chemistry, 2018, 41, 5657-5667, (2018).

[14] Feng, J., Liu, K., Li, Y. and Yang, M., A novel calixarene-containing hyperbranched aliphatic polyester incorporated with pendant europium complexes, Polymers for Advanced Technologies, 20, 6, 514-518, (2009).

[15] Nakahara, Y., Furuno, Y., Iwamoto, H., Yajima, S. and Kimura, K. A tetraester derivative of fluorescent calix[4]arene bearing a proton-ionizable moiety for highly sensitive extraction-fluorometric determination of sodium ion, Supramolecular Chemistry, 30, 8, 697-705, (2018).

[16] Uysal Akkus, G., Ala E. and Korcan, S.E., Selective extraction of toxic heavy metals and biological activity studies using pyrimidylthioamide functionalised calix[4]arene, Supramolecular Chemistry, 27, 7-8, 522-526, (2015).

[17] Sayin, S., Yildiz, H.B. and Eymur, S., Synthesis of Various Calix[4]arene Derivatives with Mercaptoalkyl Chains and Their Application in Removing Cr(VI) from Aqueous Solution, Polycyclic Aromatic Compounds, 28, 2, 120130, (2018).

[18] Sayin, S., Ozcan F. and Yilmaz, M., Two novel calixarene functionalized iron oxide magnetite nanoparticles as a platform for magnetic separation in the liquid-liquid/solid-liquid extraction of oxyanions, Materials Science and Engineering C, 33, 2433-2439, (2013).

[19] Ahuja, B.B. and Vigalok, A., Fluorescent Calixarene Scaffolds for NO Detection in Protic Media, Angewandte Chemie International Edition, 58, 9, 2774-2778, (2019). 
[20] Sahin, O. and Yilmaz, M., Synthesis and fluorescence sensing properties of a new naphthalimide derivative of calix[4]arene, Tetrahedron Letters, 53, 18, 2319-2324 (2012).

[21] Güngör, Ö., Efficient removal of carcinogenic azo dyes by novel pyrazine-2carboxylate substituted calix[4, 8]arene derivatives, Supramolecular Chemistry, 31, 12, 776-783, (2019).

[22] Kamboh, M.A., Akoz, E., Memon S. and Yilmaz, M., Synthesis of AminoSubstituted p-tert-Butylcalix[4]arene for the Removal of Chicago Sky Blue and Tropaeolin 000 Azo Dyes from Aqueous Environment, Water, Air, \& Soil Pollution, 224, 1424, (2013).

[23] Güngör, Ö., Liquid phase extraction of azo dyes by novel calixarenes bearing phthalonitrile and diiminoisoindoline groups, Separation Science and Technology, 53, 6, 896-902, (2018).

[24] Akceylan, E., Bahadir M. and Yılmaz, M., Removal efficiency of a calix[4]arene-based polymer for water-soluble carcinogenic direct azo dyes and aromatic amines, Journal of Hazardous Materials, 162, 960-966, (2009).

[25] Kamboh, M.A., Solangi, I.B., Sherazi S.T.H. and Memon, S., Synthesis and application of p-tert-butylcalix[8]arene immobilized material for the removal of azo dyes, Desalination, 268, 83-89, (2011).

[26] Kamboh, M.A., Solangi, I.B., Sherazi S.T.H. and Memon, S., Synthesis and application of p-tert-butylcalix[8]arene immobilized material for the removal of azo dyes, Journal of Hazardous Materials, 186, 651-658, (2011).

[27] Kamboh, M.A., Solangi, I.B., Sherazi S.T.H. and Memon, S., Synthesis and application of calix[4]arene based resin for the removal of azo dyes, Journal of Hazardous Materials, 172, 234-239, (2009).

[28] Thakkar, S.S., Thakor, P., Doshi, H. and Ray, A., 1,2,4-Triazole and 1,3,4oxadiazole analogues: Synthesis, MO studies, in silico molecular docking studies, antimalarial as DHFR inhibitor and antimicrobial activities, Bioorganic \& Medicinal Chemistry, 25, 15, 4064-4075, (2017).

[29] Khanam, R., Kumar, R., Hejazi, I.I., Shahabuddin, S., Meena, R., Rajamani, P., Yadav, N., Bhat, A.I. and Athar, F., New N-benzhydrylpiperazine/1,3,4-oxadiazoles conjugates inhibit the proliferation, migration, and induce apoptosis in HeLa cancer cells via oxidative stressmediated mitochondrial pathway, Journal of Cellular Biochemistry, 120, 2, 1651-1666, (2019).

[30] Özil, M., Balaydın, H.T. and Şentürk, M., Synthesis of 5-methyl-2,4-dihydro3H-1,2,4-triazole-3-one's aryl Schiff base derivatives and investigation of carbonic anhydrase and cholinesterase (AChE, BuChE) inhibitory properties, Bioorganic Chemistry, 86, 705-713, (2019).

[31] Boström, J., Hogner, A., Llinàs, A., Wellner, E. and Plowright, A.T., Oxadiazoles in Medicinal Chemistry, Journal of Medicinal Chemistry, 55, 5 1817-1830, (2012).

[32] Galstyan, A.S., Ghochikyan, T.V., Frangyan, V.R., Tamazyan, R.A. and Ayvazyan, A.G., Synthesis of Novel Derivatives of 1,2,4-Triazoles, ChemistrySelect, 3, 35, 9981-9985 (2018).

[33] Jasiak, K. and Kudelko, A., Oxidative cyclization of N-aroylhydrazones to 2-(2arylethenyl)-1,3,4-oxadiazoles using DDQ as an efficient oxidant, Tetrahedron Letters, 56, 43, 5878-5881, (2015).

[34] Zarudnitskii, E.V., Pervak, I.I., Merkulov, A.S., Yurchenko, A.A. and Tolmachev, A.A., Trimethylsilyl-1,3,4-oxadiazoles-new useful synthons for 
the synthesis of various 2,5-disubstituted-1,3,4-oxadiazoles, Tetrahedron, 64, 45, 10431-10442, (2008).

[35] Chen, Z., Liu, Y., Zhang, C. and Bai, F., Synthesis and properties of photoluminescent copolymer containing 1,3,4-oxadiazole and carbazole rings, Journal of Applied Polymer Science, 92, 5, 2777-2783, (2004).

[36] Xie, D.-H., Wang, X.-J., Sun, C. and Han, J., Calix[4]arene based 1,3,4oxadiazole as a fluorescent chemosensor for copper(II) ion detection, Tetrahedron Letters, 57, 51, 5834-5836, (2016).

[37] Jia, T.-J., Cao, W., Zheng, X.-J. and Jin, L.-P., A turn-on chemosensor based on naphthol-triazole for $\mathrm{Al}(\mathrm{III})$ and its application in bioimaging, Tetrahedron Letters, 54, 26, 3471-3474, (2013).

[38] Shalaeva, Y.V., Morozova, J.E., Mironova, D.A., Kazakova, E.K., Kadirov, M.T., Nizameev I.R. and Konovalov, A.I., Amidoamine calix[4]resorcinarenebased oligomers and polymers as efficient sorbents of azo dyes from water, Supramolecular Chemistry, 27, 9, 595-605, (2015).

[39] Memon, S., Bhatti A.A. and Bhatti, A.A., Calix[4]arene Resin, An Efficient Adsorbent for Azo Dyes, Polycyclic Aromatic Compounds, 39, 3, 238-247, (2019).

[40] Shengquan, Y., Hui, W., Chaohua Z. and Fu, H., Separation of carcinogenic aromatic amines in the food colourants plant wastewater treatment, Desalination, 222, 294-301, (2008).

[41] Hosseini, S., Khan, M.A., Malekbala, M.R., Cheah W. and Choong, T.S.Y., Carbon coated monolith, a mesoporous material for the removal of methyl orange from aqueous phase: Adsorption and desorption studies, Chemical Engineering Journal, 171, 1124- 1131, (2011).

[42] Gutsche, C.D., Iqbal, M. and Stewart, D., Calixarenes. 19. Syntheses procedures for p-tert-butylcalix[4]arene, Journal of Organic Chemistry, 51, 5, 742-745, (1986).

[43] Li, Z.-T., Ji, G.-Z., Zhao, C.-X., Yuan, S.-D., Ding, H., Huang, C., Du, A.-L. and Wei, M., Self-Assembling Calix[4]arene [2]Catenanes. Preorganization, Conformation, Selectivity, and Efficiency, Journal of Organic Chemistry, 64, 10, 3572-3584, (1999). 